\section{Apical Extrusion of Debris and Irrigants Using Different Irrigation Needles}

Paula Barcellos Silva ${ }^{1}$, Angélica Mohnsam Krolow ${ }^{1}$, Katerine Jahnecke Pilownic ${ }^{1}$, Renata Picanço Casarin¹, Regina Karla Pontes Lima², Renato de Toledo Leonardo ${ }^{2}$, Fernanda Geraldo Pappen ${ }^{1}$

\author{
'Department of Semiology and \\ Clinics, School of Dentistry, \\ UFPel - Universidade Federal de \\ Pelotas, Pelotas, RS, Brazil \\ ${ }^{2}$ Department of Restorative \\ Dentistry, Araraquara Dental School, \\ UNESP - Universidade Estadual \\ Paulista, Araraquara, SP, Brazil
}

Correspondence: Prof. Fernanda Geraldo Pappen, Rua Gonçalves Chaves, 457/507, 96015-560 Pelotas, RS, Brasil. Tel: +55-53-3222-4162. e-mail: ferpappen@yahoo.com.br

Key Words: apical extrusion, irrigation needle, endodontics, irrigation.

\section{Introduction}

Root canal irrigation is an important part of canal preparation for the removal of bacteria, debris and necrotic tissue, especially from root canal areas previously untouched by instrumentation (1). In an irrigant is not used, no significant debris extrusion occurs, but during root canal irrigation there is considerable extrusion of material $(2,3)$. Debris extrusion depends on several factors, including the apical anatomy, type and size of the irrigation needle, needle placement depth, apical preparation size and taper, and the instrumentation technique (4). The needle tip design also influences flow pattern, flow velocity and apical wall pressure, which are important parameters accounting for irrigation effectiveness and safety (5).

Several case reports have described complications in the periapical tissues caused by irrigation $(6,7)$. Extrusion of debris and irrigation solutions may be the main cause of inflammatory exacerbation (8), and could cause severe pain, burning sensation, oedema, periapical inflammation and delayed healing of apical periodontitis (6).

Most studies quantifying periapical debris and irrigant extrusion perform an experimental vial simulation and thus, fail to accurately simulate the periapical back-pressure. Only recently the investigators attempted to mimic the periapical resistance in extrusion studies $(4,9)$. Therefore, information is lacking on the factors affecting periapical irrigant and debris extrusion while accommodating periapical resistance. The present study aimed to evaluate the influence of irrigation tip, root curvature and final apical diameter on periapical debris and irrigant extrusion. The tested hypothesis is that different irrigation tips, as well as the root curvature and the apical diameter of root canal could not cause more extrusion of material to the apical tissues.

\section{Material and Methods}

The present study was approved by the Ethics Committee of the School of Dentistry of the UFPel - Universidade Federal de Pelotas (\#22/2012) and was performed in accordance with the ethical standards laid down in the 1964 Declaration of Helsinki and its later amendments.

The mesiobuccal root canals of 90 extracted human maxillary and mandibular molars with intact apices were evaluated. After the pulp cavity was accessed and soft tissues removed, a \# $10 \mathrm{~K}$-file (Dentsply Maillefer, Ballaigues, Switzerland) was inserted into the canal until its tip was slightly visible at the root apex under 20x magnification, and canal working length was determined $1 \mathrm{~mm}$ short of the apex. The minimal constriction size was controlled by advancing a \#15 K-file (Dentsply) to the working length. Teeth were excluded if the \#15 file tip extended beyond the apical foramen. 
Prior to root canal preparation, each tooth was radiographed with a \#15K-file inside the canal to determine the canal curvature (10). Each tooth was classified according to the curvature degree: a curvature angle equal or less than $10^{\circ}$ (mild curvature) or a curvature angle $11^{\circ}$ to $25^{\circ}$ (moderate curvature).

A cuboid piece of floral foam, with standardized dimensions, was attached to each specimen to simulate a slight periapical tissue resistance (4). Each foam cube was weighed three times consecutively and the mean weight was calculated. Cyanoacrylate adhesive sealed a rubber dam and the root surfaces, leaving the root canal access cavity coronally exposed. The teeth were inserted into the foam up to the cementoenamel junction. All the cubes were covered with a polyvinyl chloride (PVC) film to prevent any loss of extruded material.

Before root canal instrumentation, the teeth were randomly allocated into three groups according to the used needle type: in Group 1, irrigation was performed with an open-end flat needle (Ultradent, South Jordan, UT, USA); in Group 2, with a side-vented irrigation tip (Vista-Probe Vista Dental, Racine, WI, USA); and in Group 3, with a double side-vented needle (Ultradent).

The coronal third of each canal was flared using sizes 2-4 Gates Glidden drills (Dentsply). The apical diameter was determined and the apical part of root canal was shaped using four Flexofile ${ }^{\oplus}$ hand instruments (Dentsply) to a final diameter varying from \#30 to \#45. The remaining canal length was gradually sloped increasing the instrument size. During instrumentation, the root canal was irrigated with 1 $\mathrm{mL} 2.5 \%$ sodium hypochlorite $(\mathrm{NaOCl})$ after each instrument change; $5 \mathrm{~mL} \mathrm{NaOCl}$ were used in the final root irrigation.

The irrigation tips were inserted apically to within 3 $\mathrm{mm}$ of the working length, and the needle was constantly pulsed 1-2 $\mathrm{mm}$ in the apical to coronal direction during irrigation. The flow of irrigant was standardized to a constant speed of $0.26 \mathrm{~mL} / \mathrm{s}$ (11).

After instrumentation, the teeth were removed from the apparatus and each foam cube was weighted three times on a precision scale. The weight difference between initial and final recordings was calculated to determine the amount of extruded material.

Data were analyzed statistically and group differences calculated using SPSS statistical software (version 17.0, SPSS, Inc., Chicago, IL, USA). Kolmogorov-Smirnov tests demonstrated that the data were not normally distributed $(p<0.05)$. Non-parametric tests compared the differences between groups.

The differences in irrigant and debris extrusion between the experimental groups were analyzed with the Mann-Whitney $\mathrm{U}$ test. Irrigation tips and final instrument diameter differences were analyzed with the Kruskal-Wallis test. Multiple groups were compared using the Mann-Whitney $U$ test with a Bonferroni correction at $p=0.05$.

\section{Results}

The groups extruding the most to least material were as follows: open-ended flat needle > side-vented irrigation tip > double side-vented needle. The amount of apically extruded debris and irrigant was significantly different among the three irrigation tips ( $p=0.034)$, as summarized in Table 1. The amount of extruded material from the double side-vented needle was significantly less than the openended flat needle $(p=0.008)$, but there was no difference compared to the side-vented needle $(\mathrm{p}=0.929)$.

There were no statistically significant differences between the irrigant and debris extrusion associated with mild or moderate root canal curvatures $(p=0.990)$ (Table 1) or the final instrument diameter $(p=0.498)$ (Table 2).

\section{Discussion}

Irrigation needles are designed primarily to maximize effective irrigation while protecting the periapical tissues. Studies determining the best irrigation needle design are lacking and therefore, newly designed irrigation tips are constantly introduced on the market $(5,12)$. The present results showed that the flat open-ended needle caused more debris and irrigant extrusion than either side-vented needles. This is consistent with recent in vitrostudies, which demonstrated that side-vented needles decrease material extrusion into the periapical tissues $(4,9,13)$.

Most in vitro extrusion studies do not attempt to simulate adjacent vital pulp or periapical tissues $(3,14,15)$. Yet, these tissues act as a natural barrier preventing or diminishing debris extrusion and therefore, such results should not be directly extrapolated at the dental clinic.

Table 1. Amount of periapical extrusion during root canal preparation according to the irrigation needle type and root canal curvature

\begin{tabular}{lccccc}
\hline \multirow{2}{*}{ Irrigation tip } & $\begin{array}{c}\text { Root canal } \\
\text { curvature }\end{array}$ & \multicolumn{4}{c}{ Irrigant and debris extrusion (grams) } \\
\cline { 3 - 6 } & Number & Median & Maximum & Minimum \\
\hline \multirow{2}{*}{ Flat open-ended } & Mild $^{\mathrm{a}}$ & 15 & 0.71 & 9.41 & 0.01 \\
& Moderate $^{\mathrm{b}}$ & 15 & 0.59 & 8.76 & 0.02 \\
Side-vented & Mild & 16 & 0.07 & 8.77 & 0.01 \\
& Moderate & 14 & 0.30 & 4.29 & 0.01 \\
\multirow{2}{*}{ Double side-vented } & Mild & 20 & 0.09 & 8.47 & 0.01 \\
& Moderate & 10 & 0.03 & 9.61 & 0.01 \\
\hline
\end{tabular}

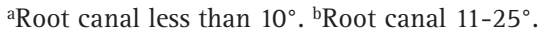


In the present study, back-pressure from periapical tissue was simulated in vitro (4). In this model, the floral foam was the best in simulating the periapical tissue resistance to debris and irrigant extrusion. It is important to mention that the present study did not aim to distinguish between the extruded amounts of debris and irrigant; both materials are extruded apically and both potentially cause periapical inflammation, postoperative pain and delayed healing, as previously demonstrated (16).

Penetration depth of the irrigation needle affects irrigant extrusion and apical needle placement improves cleaning and disinfection $(17,18)$. In this study, during the root canal irrigation, the needle was up to $3 \mathrm{~mm}$ short of the working length. These results consequently reflect extrusion using the presumably safe apical position of irrigant tips. The further the needle is positioned from the working length, the less apical pressure is developed, but the irrigant exchange becomes less efficient and wall shear stress is lowered. The ideal position, using open-end needles, is $2 \mathrm{~mm}$ or $3 \mathrm{~mm}$ short of the apex to ensure adequate irrigant flow through the root canal (11). Thus, this study standardized other recommendations for needle irrigation, like avoiding needle binding into the root canal walls and irrigating at a constant $0.25 \mathrm{~mL} / \mathrm{s}$ to avoid pushing material into the periapex. The amount of $\mathrm{NaOCl}$ delivered during instrumentation was also standardized to allow direct comparisons among the different delivery methods.

The present study results suggest that periapical debris extrusion is independent of the final apical diameter after root canal preparation, which agrees with Psimma et al.

Table 2. Amount of periapical extrusion of debris and irrigant during root canal preparation according to irrigation needle type and final apical diameter

\begin{tabular}{lccccc}
\hline \multirow{2}{*}{$\begin{array}{l}\text { Irrigation } \\
\text { tip }\end{array}$} & $\begin{array}{c}\text { Final apical } \\
\text { diameter } \\
(\mathrm{mm})\end{array}$ & \multicolumn{4}{c}{ Irrigant and debris extrusion (grams) } \\
\cline { 3 - 6 } & 0.30 & 18 & 0.48 & 8.56 & 0.005 \\
\hline \multirow{2}{*}{$\begin{array}{l}\text { Flat open- } \\
\text { ended }\end{array}$} & 0.35 & 9 & 2.98 & 9.41 & 0.03 \\
& 0.40 & 3 & 0.05 & 0.48 & 0.02 \\
& 0.45 & 0 & - & - & - \\
& 0.30 & 12 & 0.92 & 5.03 & 0.0006 \\
Side-vented & 0.35 & 10 & 0.01 & 4.29 & 0.0002 \\
& 0.40 & 5 & 0.01 & 4.12 & 0.0004 \\
& 0.45 & 3 & 6.17 & 8.77 & 1.76 \\
& 0.30 & 13 & 0.02 & 4.63 & 0.0004 \\
& 0.35 & 10 & 1.10 & 9.61 & 0.0007 \\
$\begin{array}{l}\text { Double } \\
\text { side-vented }\end{array}$ & 0.40 & 2 & 1.15 & 2.22 & 0.09 \\
& 0.45 & 5 & 0.53 & 1.63 & 0.0004 \\
\hline
\end{tabular}

(9). However, it should be observed that the anatomical foramen size was controlled by advancing a \#15 K file to the working length; any tooth where the file tip extended beyond the apical foramen was excluded. Thus, the final apical diameter ranged only $0.30-0.45 \mathrm{~mm}$. Previously, 0.30 $\mathrm{mm}$ instruments were confirmed to produce the minimal enlargement required for adequate irrigation of the apical third of the canal (19); larger instruments enabled improved canal wall contact and thus, more effective cleaning (20). The final apical diameter range in this study was selected based on these previous findings.

The results also indicate that root canal curvature was not a factor affecting the amount of periapical debris extrusion, despite prior studies finding that straight or mildly curved root canals generate a higher irrigation pressure than moderate or highly curved canals. Such findings agree with Psimma et al. (9), but contradict those of Borges et al.(15), who demonstrated that root canals curved between $10^{\circ}$ and $25^{\circ}$ and apically prepared with \#45.02 instruments had increased periapical irrigant and debris extrusion. Importantly, this contradiction may reflect the investigator's use of anterior teeth, which present improved foramen alignment with the root long axis (21). Deviation frequency in the main foramen is significantly higher in posterior teeth (43\%) than anterior teeth (17\%), regardless of root canal curvature (22).

Similar to other studies, the present results demonstrated that double side-port needles extruded less debris and irrigant compared to flat-open needles $(4,12)$. Other studies failed to compare double side-port and one sideport needles. Open-end tips in particular can create high and unpredictable apical pressures (23), but extrusion may still occur even with closed-end needles because the root canal cross section is not precisely circular, therefore, the needle tip may not block completely irrigant access to the apical root canal (9).

Investigations of the needle-tip design showed that open-end needles produce higher apical irrigation pressure because the design enables direct periapical access of the solution (11). In contrast, the side vented needles allow the irrigation solutions to move through the root canal walls rather than apically. Consequently, the higher pressure at the apical foramen, as well as the improved irrigant replacement and higher canal wall shear stress associated with open ended needles, may increase the risk of periapical irrigant and debris extrusion $(11,24,25)$. Needle tip design clearly influences the flow pattern, solution speed and apical wall pressure, which are all important parameters determining irrigation effectiveness and safety. Thus, it is 
recommended that any needle, irrespective of design, lie passively in the canal and avoids engaging the walls (5).

The irrigation needle type greatly influences the irrigant and debris extrusion, and double side-vented needles decrease periapical extrusion of material. Furthermore, there were no statistically significant differences in the amount of irrigant and debris associated with mild and moderate root canal curvatures or in final apical diameter.

\section{Resumo}

Este estudo avaliou a influência do tipo de agulha de irrigação, curvatura do canal radicular e diâmetro apical final sobre a extrusão de detritos e solução irrigadora durante o preparo físico-químico do canal radicular. 0 canal mésio- vestibular de 90 molares foi instrumentado, após ser classificado como de curvatura leve ou moderada. Os dentes foram divididos de acordo com o tipo de agulha utilizada em 3 grupos: agulha de extremidade aberta (Grupo 1), agulha de extremidade fechada com abertura lateral (Grupo 2) ou agulha de extremidade fechada com dupla abertura lateral (Grupo 3). A quantidade de material extruído após a instrumentação foi calculada em cada grupo. As diferenças de extrusão de solução irrigadora e detritos entre os grupos experimentais foram analisados com o teste de Mann-Whitney. As diferenças entre o tipo de agulha de irrigação e o diâmetro apical final foram analisados com o teste de Kruskal-Wallis. Grupos múltiplos foram comparados usando o teste U de Mann-Whitney com correção de Bonferroni em $\alpha=0,05$. A quantidade de material extruído pela agulha de extremidade fechada com dupla abertura lateral foi significativamente menor do que a agulha de extremidade aberta $(p=0,008)$, porém não houve diferença em relação a agulha de extremidade fechada com abertura lateral $(p=0,929)$. Os resultados não indicaram relação entre a curvatura radicular e o diâmetro apical final sobre a quantidade de solução irrigante e detritos de extruídos $(p>0,05)$. 0 uso de agulhas com dupla abertura lateral resultaram em uma menor extrusão de material aos tecidos periapicais. 0 tipo de agulha de irrigação teve a maior influência sobre extrusão periapical de solução irrigadora e detritos. As agulhas de extremidade fechada com dupla abertura lateral podem ser utilizadas com segurança durante a terapia endodôntica.

\section{References}

1. Gulabivala K, Patel B, Evans G, Ng YL. Effects of mechanical and chemical procedures on root canal surfaces. Endodontic Topics 2005;10:103-122.

2. Van der Sluis LW, Gambarini G, Wu MK, Wesselink PR. The influence of volume, type of irrigant and flushing method on removing artificially placed dentine debris from the apical root canal during passive ultrasonic irrigation. Int Endod J 2006;39:472-476.

3. Uzunoglu E, Turker SA, Görduysus M. Effects of different rotary files combined with different irrigation needles on apically extruded debris. Braz Dent J 2015;26:347-350.

4. Altundasar E, Nagas E, Uyanik O, Serper. Debris and irrigant extrusion potential of 2 rotary systems and irrigation needles. Oral Surg Oral Med Oral Pathol Oral Radiol and Endod 2011;112:e31-e35.

5. Shen Y, Gao Y, Qian W, Ruse ND, Zhou X, Wu H, et al.. Three-dimensional numeric simulation of root canal irrigant flow with different irrigation needles. J Endod 2010;36:884-889.

6. Gernhardt CR, Eppendorf K, Kozlowski A, Brandt M. Toxicity of concentrated sodium hypochlorite used as an endodontic irrigant. Int Endod J 2004;37:272-280.
7. Behrents KT, Speer ML, Noujeim M. Sodium hypochlorite accident with evaluation by cone beam computed tomography. Int Endod J 2012:45:492-498.

8. Siqueira, JF. Microbial causes of endodontic flare-ups. Int Endod J 2003;36:453-513.

9. Psimma Z, Boutsioukis C, Kastrinakis E, Vasiliadis E. Effect of needle insertion depth and root canal curvature on irrigant extrusion ex vivo. J Endod 2013;39:521-524.

10. Schneider SW. A comparison of canal preparations in straight and curved canals. Oral Surg, Oral Med, and Oral Pathol 1971;32:271-276.

11. Boutsioukis C, Lambrianidis $T$, Verhaagen B, Versluis M, Kastrinakis $E_{1}$ Wesselink PR, et al.. The effect of needle-insertion depth on the irrigant flow in the root canal: evaluation using an unsteady computational fluid dynamics model. J Endod 2010;36:1664-1672.

12. Yeter KY, Evcil MS, Ayranci LB, Ersoy I. Weight of apically extruded debris following use of two canal instrumentation techniques and two designs of irrigation needles. Int Endod J 2013;46:795-799.

13. Yost RA, Bergeron BE, Kirkpatrick TC, Roberts MD, Roberts HW, Himel VT, et al.. Evaluation of 4 different irrigating systems for apical extrusion of sodium hypochlorite. J Endod 2015;41:1530-1534.

14. Farmakis ET, Sotiropoulos GG, Abràmovitz I, Solomonov M. Apical debris extrusion associated with oval shaped canals: a comparative study of WaveOne vs Self-Adjusting File. Clin Oral Investig 2016 Jan 12. [Epub ahead of print].

15. Borges MFA, Miranda CES, Silva SRC, Marchesan M. Influence of apical enlargement in cleaning and extrusion in canals with mild and moderate curvatures. Braz Dent J 2011;22:212-217.

16. Lambrianidis $T$, Tosounidou $E$, Tzoanopoulou M. The effect of maintaining apical patency on periapical extrusion. J Endod 2001;27:696-698.

17. Wang R, Shen $Y$, Ma J, Huang D, Zhou X, Gao Y, Haapasalo M. Evaluation of the effect of needle position on irrigant flow in the C-shaped root canal using a computational fluid dynamics model. J Endod 2015:41:931-936.

18. Sedgley CM, Nagel AC, Hall D, Applegate B. Influence of irrigant needle depth in removing bioluminescent bacteria inoculated into instrumented root canals using real-time imaging in vitro. Int Endod J 2005;38:97-104.

19. Khademi $A$, Yazdizadeh $M$, Feizianfard M. Determination of the minimum instrumentation size for penetration of irrigants to the apical third of root canal systems. J Endod 2006;32:417-420

20. Fornari VJ, Silva-Souza YTC, Vanni JR, Pécora DJ, Versiani MA, SouzaNeto MD. Histological evaluation of the effetiveness of increased apical enlargement for cleaning the apical third of curved canals. Int Endod J 2010;43:988-994.

21. Ferraz CC, Gomes NV, Gomes BP, Zaia AA, Teixeira FB, Souza-Filho FJ. Apical extrusion of debris and irrigants using two hand and three engine-driven instrumentation techniques. Int Endod J 2001;34:354358.

22. Martos J, Ferrer-Luque CM, González-Rodríguez MP, Castro LA. Topographical evaluation of the major apical foramen in permanent human teeth. Int Endod J 2009;42:329-363.

23. Park E, Shen $Y$, Khakpour M, Haapasalo M. Apical pressure and extent of irrigant flow beyond the needle tip during positive-pressure irrigation in an in vitro root canal model J Endod 2013;39:511-515.

24. Boutsioukis C, Lambrianidis $T$, Kastrinakis E. Irrigant flow within a prepared root canal using different flow rates: a computational fluid dynamics study. Int Endod J 2009;42:144-155.

25. Boutsioukis C, Psimma Z, Kastrinakis E. The effect of flow rate and agitation technique on irrigant extrusion ex vivo. Int Endod J 2013;46:1-10. 